\title{
EBM in Brazil and the Creation of the Oxford-Brazil EBM Alliance
}

Rachel Riera ${ }^{\mathrm{I}}$, Enderson Miranda ${ }^{\mathrm{II}}$, Luis Eduardo Santos Fontes ${ }^{\mathrm{III}}$, Rafael Leite Pacheco ${ }^{\mathrm{IV}}$, David Nunan ${ }^{\mathrm{V}}$

I Discipline of Evidence-Based Medicine, Escola Paulista de Medicina, Universidade Federal de São Paulo (Unifesp). Centre of Health Technology Assessment, Hospital Sírio-Libanês. OxfordBrazil EBM Alliance. Email: rachelriera@hotmail.com

II University of Oxford, Centre for Evidence Based Medicine (CEBM), Oxford, UK. OxfordBrazil EBM Alliance. Email: enderson.miranda@kellogg.ox.ac.uk

III Faculdade de Medicina de Petrópolis. Cochrane Brazil - Rio de Janeiro Affiliate Centre. Centre for Evidence-Based Medicine (CEBM) - University of Oxford. Oxford-Brazil EBM Alliance. Email: 1uis.fontes@,ceo2.com.br / scat7654@ox.ac.uk

IV Centro Universitário São Camilo, São Paulo. Universidade Federal de São Paulo (Unifesp). Oxford-Brazil EBM Alliance. Email: rleitepacheco@hotmail.com

${ }^{\mathrm{V}}$ Centre for Evidence Based Medicine (CEBM), Nuffield Department of Primary Care, Health Sciences, University of Oxford. Email: david.nunan@phc.ox.ac.uk

Corresponding author: Luis Eduardo Santos Fontes. Oxford-Brazil EBM Alliance. E-mail: luis.fontes@ceo2.com.br

Funding sources: None.

Conflict of interest: None declared.

Keywords: Evidence-Based Medicine; Evidence-Based Practice; Support of Research; Teaching. 


\section{EVIDENCE-BASED MEDICINE IN BRAZIL}

The key concepts of Evidence-Based Medicine (EBM) arrived in Brazil in the mid-90s and gave rise to considerable activities and initiatives to disseminate its use and importance in the decision process of health care. Table 1 outlines, but not exhaustively, the various EBM-related initiatives in Brazil from 1997 to 2019 that we have identified, either through informal online searches, reports of our own experiences, and collaborations with local colleagues currently involved with EBM in Brazil.

Table 1. EBM-Related Initiatives in Brazil (1997-2019)

\begin{tabular}{|c|c|c|}
\hline Area & Activity/action & Description \\
\hline \multirow{4}{*}{ Teaching } & $\mathrm{MSc}$ and $\mathrm{PhD}$ programs & $\begin{array}{l}\text { In 1997, a post-graduation program in Evidence-Based } \\
\text { Health Care is offered at the Universidade Federal de São } \\
\text { Paulo [1]. Other post-graduation programs offered EBM- } \\
\text { related contend as disciplines, but they were not mapped to } \\
\text { MSc or PhD programs yet. }\end{array}$ \\
\hline & Academic Leagues & $\begin{array}{l}\text { The first Brazilian EBM undergraduate academic league was } \\
\text { created in } 2013 \text { at Universidade Federal de São Paulo [2]. }\end{array}$ \\
\hline & $\begin{array}{l}\text { Undergraduate } \\
\text { (Medicine Courses) }\end{array}$ & $\begin{array}{l}\text { By } 2007,13.6 \% \text { of medical schools ( } 23 \text { out of } 169 \text { ) included } \\
\text { formal EBM content in their curricula [3]. An ongoing } \\
\text { survey is attempting to update these figures but most recent } \\
\text { data is not yet available. }\end{array}$ \\
\hline & $\begin{array}{l}\text { Undergraduate } \\
\text { (Other Healthcare Courses) }\end{array}$ & $\begin{array}{l}\text { Other healthcare-related undergraduate courses incorporate } \\
\text { Evidence Based Health Care in their curricula, but no formal } \\
\text { assessment has been performed or published so far. }\end{array}$ \\
\hline \multirow{3}{*}{ Learning } & Distance Learning Courses & $\begin{array}{l}\text { Between } 2005 \text { and } 2016 \text {, a year-long distance learning course } \\
\text { (300 hours) on EBM for healthcare professionals had been } \\
\text { conducted. By } 2009 \text {, there were approximately } 3,500 \\
\text { professionals regularly attending the course [4]. }\end{array}$ \\
\hline & $\begin{array}{c}\text { In Person Short-Duration } \\
\text { Courses }\end{array}$ & $\begin{array}{l}\text { Short-duration EBM courses have been offered in Brazil as } \\
\text { the Evidence-based Clinical Practice conducted through a } \\
\text { partnership with McMaster University [5]. There was no } \\
\text { formal mapping of all short-duration courses. }\end{array}$ \\
\hline & $\begin{array}{l}\text { Medicine and Journalism } \\
\text { Courses }\end{array}$ & $\begin{array}{l}\text { Since } 2018 \text {, a series of courses have been offered in Brazil } \\
\text { focusing on educating and helping journalists to properly } \\
\text { disseminate EBM concepts in health-related news [6]. }\end{array}$ \\
\hline
\end{tabular}




\begin{tabular}{|c|c|c|}
\hline \multirow[t]{2}{*}{$\begin{array}{l}\text { Knowledge } \\
\text { Translation }\end{array}$} & $\begin{array}{l}\text { Translations of Cochrane } \\
\text { Review's Abstracts and Plain } \\
\text { Language Summaries (PLS) }\end{array}$ & $\begin{array}{l}\text { In 2013, Cochrane Brazil established a network of } \\
\text { collaborative volunteer hubs to aid the translation of } \\
\text { Cochrane Review's abstracts and plain language summaries } \\
{[7,8] \text {. Cochrane Brazil continues to translate Cochrane }} \\
\text { evidence to this day, including podcasts [9] and other } \\
\text { multimedia resources available to Cochrane's consumers. }\end{array}$ \\
\hline & $\begin{array}{l}\text { Students } 4 \text { Best Evidence } \\
\text { (S4BE) Posts }\end{array}$ & $\begin{array}{c}\text { Since 2016, S4BE posts have been translated to Portuguese } \\
\text { by volunteers [10]. }\end{array}$ \\
\hline \multirow[b]{2}{*}{$\begin{array}{c}\text { Health Care } \\
\text { Law and } \\
\text { Judicialization }\end{array}$} & Federal Law & $\begin{array}{l}\text { In 2011, Brazilian federal law } 12.401 \text { was passed, } \\
\text { establishing that new technologies might only be } \\
\text { incorporated into Brazilian public health care if their efficacy } \\
\text { and safety is established by an independent committee [11]. }\end{array}$ \\
\hline & National Justice Council & $\begin{array}{l}\text { The Brazilian National Justice Council established a } \\
\text { partnership with the Brazilian Ministry of Health to improve } \\
\text { health-related decision-making using evidence-based health } \\
\text { care on judicialization cases. One of the main achievements } \\
\text { of this initiative was the establishment of the e-NatJus, which } \\
\text { is an online repository to house technical reports that support } \\
\text { the decision-making process in judicialization }[12,13] \text {. }\end{array}$ \\
\hline $\begin{array}{l}\text { Scientific } \\
\text { Events }\end{array}$ & $\begin{array}{l}\text { International EBM-Related } \\
\text { Events Hosted in Brazil }\end{array}$ & $\begin{array}{l}\text { In 2007, São Paulo held the } 15^{\text {th }} \text { Cochrane Colloquium under } \\
\text { the theme 'Evidence-Based Health Care For All' [14]. In } \\
\text { 2011, Rio de Janeiro hosted the HTAi Annual meeting [15]. }\end{array}$ \\
\hline \multirow[t]{2}{*}{$\begin{array}{l}\text { Scientific } \\
\text { Journals }\end{array}$} & $\begin{array}{l}\text { São Paulo Medical Journal / } \\
\text { Evidence for Healthcare }\end{array}$ & $\begin{array}{l}\text { Founded in 1932, this journal is one of the } \\
\text { oldest medical publications in Brazil. It is printed bimonthly, } \\
\text { in English, with open access, indexed in MEDLINE, Lilacs, } \\
\text { SciELO, Science Citation Index Expanded, Journal Citation } \\
\text { Reports/Science Edition. Over the past } 15 \text { years, the journal } \\
\text { has prioritized the publication of systematic reviews. } \\
\text { Furthermore, the journal offers a standing section that } \\
\text { resulted from a collaboration with Cochrane Brazil, where } \\
\text { Cochrane Review summaries are published on diverse topics. } \\
\text { (http://associacaopaulistamedicina.org.br/atualizacao- } \\
\text { medica/revista-spmi) }\end{array}$ \\
\hline & $\begin{array}{l}\text { Revista Diagnóstico e } \\
\text { Tratamento } \\
\text { (Diagnostic and Treatment } \\
\text { Journal) }\end{array}$ & $\begin{array}{l}\text { Launched in 1996, this journal is printed four times per year } \\
\text { in Portuguese language, with open access, and is indexed in } \\
\text { the LILACS database. The journal aims to provide medical } \\
\text { updates based on the best available evidence. It includes a } \\
\text { standing section, which resulted from a collaboration with } \\
\text { Cochrane Brazil, where Cochrane Review summaries are } \\
\text { published on diverse topics, as well as an Evidence-based } \\
\text { Medicine section, which is focused on methodological issues. } \\
\text { (http://associacaopaulistamedicina.org.br/atualizacao- } \\
\text { medica/revista-rdt) }\end{array}$ \\
\hline
\end{tabular}




\begin{tabular}{|c|c|c|}
\hline & $\begin{array}{c}\text { Journal of Evidence-Based } \\
\text { Healthcare }\end{array}$ & $\begin{array}{l}\text { Launched in 2018, this journal is printed bimonthly, in } \\
\text { English, with open access. It is totally focused on EBM, with } \\
\text { the mission to foster evidence-based knowledge in the } \\
\text { biomedical and life sciences. } \\
\text { (https://www5.bahiana.edu.br/index.php/evidence) }\end{array}$ \\
\hline \multirow[t]{3}{*}{ Public Policies } & $\begin{array}{c}\text { REBRATS } \\
\text { (Rede Brasileira de Avaliação } \\
\text { de Tecnologias em Saúde) }\end{array}$ & $\begin{array}{l}\text { Brazilian Health Technology Assessment (HTA) Network is } \\
\text { supported by the Brazilian Ministry of Health and comprised } \\
\text { of } 123 \text { centers throughout all Brazilian regions. One of the } \\
\text { main objectives of these centers is to use concepts and } \\
\text { methods of EBM for elaborating evidence synthesis and } \\
\text { disseminating healthcare evidence in the field of Health } \\
\text { Technology Assessment }[16,17] \text {. } \\
\text { (http://rebrats.saude.gov.br/) }\end{array}$ \\
\hline & $\begin{array}{c}\text { Conitec } \\
\text { (Comissão Nacional de } \\
\text { Incorporação de Tecnologias) }\end{array}$ & $\begin{array}{l}\text { National Commission for the Incorporation of Technologies } \\
\text { in the Brazilian public health system (SUS). This HTA } \\
\text { agency was created in } 2011 \text { and provides EBM } \\
\text { recommendations for the Brazilian Ministry of Health [11]. } \\
\text { (http://conitec.gov.br/) }\end{array}$ \\
\hline & Evidence-Informed Policies & $\begin{array}{l}\text { Through an initial partnership with EVIP Net Brasil, the } \\
\text { Brazilian Ministry of Health has supported the development } \\
\text { of activities related to evidence-informed policies in } \\
\text { healthcare [18]. } \\
\text { (http://brasil.evipnet.org/) }\end{array}$ \\
\hline
\end{tabular}

A milestone in the history of EBM in Brazil was the launch of the Brazilian Cochrane Centre in 1996 (now called Cochrane Brazil). Twenty years later, the Cochrane Brazilian Network was created, which today has five affiliated centers. Since 2011 there has been a significant growth in the number of centers using EBM concepts and methodologies for elaborating evidence synthesis and disseminating healthcare evidence in the field of Health Technology Assessment (ATS). This substantial growth is attributed to the creation of the Brazilian Health Technology Assessment Network, which is supported by the Brazilian Ministry of Health (REBRATS, Rede Brasileira de Avaliação de Tecnologias em Saúde) [16]. Today there are 123 such centers in Brazil, namely Health Technology Assessment Centers (NATS, Núcleos de Avaliação de Tecnologias em Saúde), the majority of which focus on research with a small number also promoting teaching activities and dissemination of EBM concepts [16]. 
Despite the highlighted and other initiatives, Brazil has not yet reached maturity as a producer of a critical scientific research body in the field of EBM. Creation of a larger and cohesive EBM network that produces outputs internationally recognized in the field would go a long way towards this goal. Such a network would have the power to perpetuate an evidence-driven scientific mindset and good practice of EBM for current and future generations of practitioners, researchers, and educators in Brazil.

Several misconceptions related to evidence-based medicine and health care exist in Brazil. Such misconceptions can lead to resistance against the term 'EBM' and contribute to a misinterpretation of its definition and core principles, primarily amongst those who are not particularly familiar with them due to their medical education training. Paradoxically, a major concern emerges from the rapid and exponential growth in the proliferation of EBM throughout Brazil, which would most often be seen as a desirable and welcomed situation. Such expeditious dissemination requires additional care to ensure that knowledge generation, translation, and dissemination are not performed through an indiscriminate process that might overlook core concepts of epidemiology and biostatistics. Such a situation could lead to the use of inappropriate methodological approaches and consequently contribute to biased evidence and interpretations thereof.

The need for the consolidation of existing local EBM practices and implementation of sustainability strategies for the expansion and improvement of EBM in Brazil became apparent to us. In response we have formed the first formal collaboration between a Latin American country and the University of Oxford's Centre for Evidence-Based Medicine (CEBM) [19].

\section{THE CREATION OF THE OXFORD-BRAZIL EBM ALLIANCE}

The initial idea to create a collaboration with Oxford occurred when two of us, Luis Eduardo Fontes and Enderson Miranda, met while attending a Teaching EBM course in 2017 as part of our post-graduate MSc in Evidence-Based Health Care at the University of Oxford. We joined David Nunan, lead tutor of the Teaching EBM course and a senior research fellow from Oxford's Centre for Evidence-Based Medicine (CEBM), to start planning the future Alliance [19]. 
The creation of the Oxford-Brazil EBM Alliance (logo displayed in Figure 1) was finally announced on June $11^{\text {th }}$,2019, with the inclusion of a third Brazilian EBM teacher and researcher, Rachel Riera, as a founding member. The project is underpinned by the concept of creating and developing a 'Centre of excellence in EBM teaching and training', which hopes to become a standard bearer and reference centre, not only in Brazil but also for all South America countries [19]. The activities and purposes of the Alliance can be primarily grouped into three pillars:

1. To promote teaching, learning, practice, and evaluation of Evidence-Based Medicine (EBM) and Evidence-Based Health Care (EBHC) in Brazil;

2. To conduct applied, patient-centric, and methodologically sound research in order to generate new knowledge required for the practice of EBHC;

3. To promote national and international collaborations with like-minded academics, educators, and scientists for developing and delivering high-quality teaching, training, and research programmes in EBM and EBHC.

Initial activities already steamed by the Alliance include:

- In June of 2019, the Alliance held the inaugural edition of the 3-day workshop 'Teaching EBM' which is tailored for medical educators, in Petrópolis, Rio de Janeiro. The workshop was capped at 24 participants and it sold out in record time. The demand was substantial and the Alliance already has a waiting list for subsequent workshops. Professors and facilitators from Oxford and Brazil carried out the teaching and facilitated the discussions;

- The Alliance has translated the following six CEBM Critical Appraisal tools from the CEBM into Portuguese (https://www.cebm.net/2014/06/critical-appraisal): systematic reviews, diagnostic, prognostic randomized clinical trials, qualitative studies, and individual patient data reviews;

- The Alliance has translated 52 biases listed on the CEBM Catalog of Bias into Portuguese (available soon: https://catalogofbias.org) and will continue to translate new biases as they are posted to the Catalog of Bias;

- Creation of a Brazilian EBM Virtual Academic Network, which already has 44 active members as of August 2019. 
Ongoing projects and future activities include:

- The next edition of the 'Teaching EBM' workshop will be held in São Paulo;

- Workshops on systematic/critical appraisal and on reporting guidelines.

- A survey to update the mapping of formal EBM disciplines in the curricula for medical undergraduate courses in Brazil.

- Promoting a sustainability project involving EBM for kids and adolescents. The project focuses on the meaningful dissemination of EBM concepts and findings for children in schools (currently in application process with governmental funding agency).

- Creation of an integrated network of Brazilian EBM academic leagues through a partnership with the EBM Academic League of Escola Paulista de Medicina, Universidade Federal de São Paulo.

Several other concurrent efforts to disseminate the activities and principles of the Oxford-Brazil EBM Alliance are taking place throughout Brazil and internationally. For instance, the creation of the Alliance was debated in the EBM-Live Conference in 2019, held at the University of Oxford, UK. An abstract was accepted for presentation at the 26th Cochrane Colloquium in November of 2019 (cancelled due to political unrest in the host city Santiago). In Brazil, founding members are disseminating the existence of the Alliance during local academic events and identifying potential collaborators and tutors. Several social media accounts have been created, including Twitter (@OxfordBrazilEBM), LinkedIn (www.linkedin.com/mwlite/company/oxford-brazil-ebmalliance), Instagram, and Facebook (www.facebook.com/Oxford-Brazil-EBM-Alliance). The classroom materials and slides from workshops will be available in the Alliance's official website (https://oxfordbrazilebm.com). The site will also include methodological tools in Portuguese and key articles to promote EBM best practices as well as the high-quality research, teaching, and practice of EBM. Ultimately, the Oxford-Brazil EBM Alliance aims to establish a strong academic partnership between Brazil and Oxford's CEBM by conducting collaborative research projects and increasing the participation of Brazilians in CEBM activities and courses via funded scholarships and visiting fellowships.

\section{CONCLUSION}


The creation of an academic EBM network has the potential to foster collaboration between researchers from different regions of Brazil and the UK, establishing permanent contact networks, encouraging common projects and activities, coordinating efforts that support the consistent and efficient dissemination of EBM as well as development of future leaders in Brazil. We are hopeful that the Oxford-Brazil EBM Alliance will contribute to the continued evolution of EBM in Brazil and Latin America by empowering the united actions from volunteers and EBM enthusiasts while removing language or geographical barriers between countries.

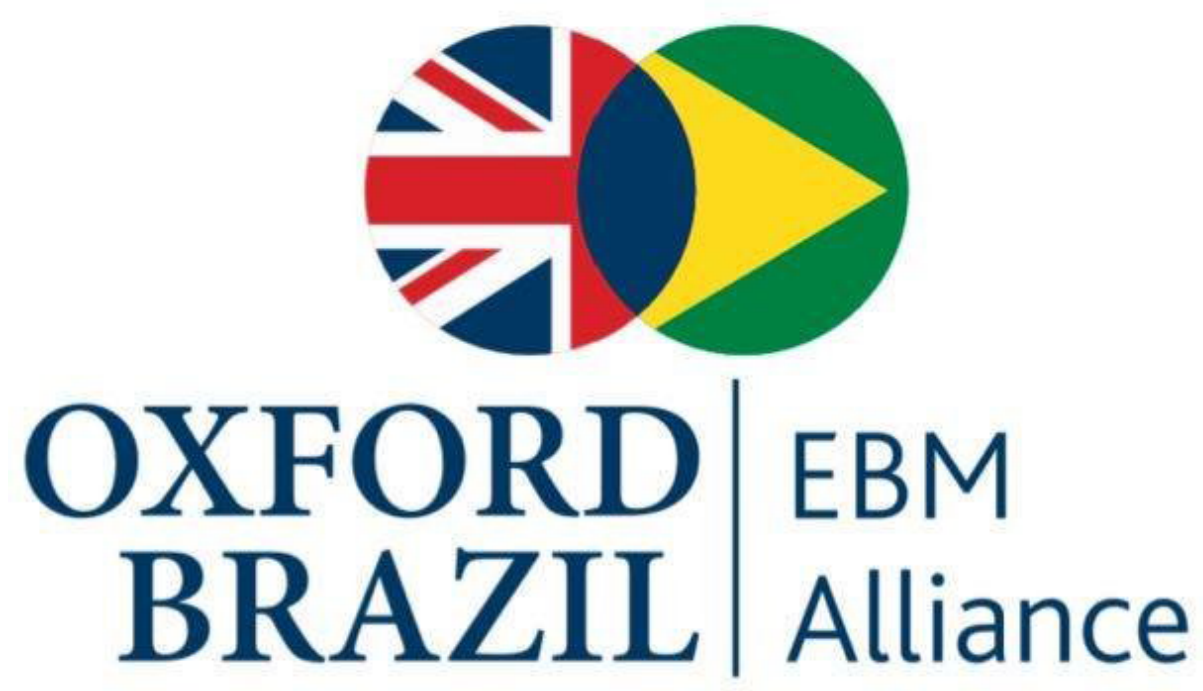

Figure 1. The Oxford-Brazil EBM Alliance logo.

\section{REFERENCES}

[1] Programa de Pós-Graduação em Saúde Baseada em Evidências. Available from: http://www.unifesp.br/reitoria/propgpq/pos-graduacao/stricto-sensu/cursos/mestrado-edoutorado/?codCAPES=33009015045P8\&uu=4. Accessed at 14 August 2019. 
[2] Daou J, Atallah AN, Barroso G, Costa I, Paroni R, Porfírio GJM, Gois AFT, Riera R. Development of the first Academic League of Evidence-based Medicine in Brazil. A partnership between the Brazilian Cochrane Centre and Universidade Federal de São Paulo. In: 23rd Cochrane Colloquium, 2015, Vienna. Abstracts of the 23rd Cochrane Colloquium, 2015. Available from:https://abstracts.cochrane.org/2015-vienna/development-firstacademic-league-evidence-based-medicine-brazil-partnership-between. Accessed on 6 August 2019.

[3] Puga MES, Atallah MBE. Mapeamento do ensino de Medicina baseada em evidências nos currículos das escolas médicas do Brasil. Available from: http://repositorio.unifesp.br/handle/11600/39237. Accessed on 6 August 2019.

[4] Macedo CR, Macedo EC, Torloni MR, Atallah ÁN. Evaluation of a national evidencebased health care course via teleconference in a developing country. J Eval Clin Pract. 2013;19(4):713-9. doi: 10.1111/jep.12063.

[5] Prática clinica baseada em evidências. Available from: https://www.ebcp.com.br/workshop/index.php. Accessed on 28 August 2019.

[6] Teixeira TDBF, Pacheco R, Torloni MR, Riera R. Teaching Brazilian journalism students about evidence-based health care: preliminary results of a randomized trial. In:25rd Cochrane Colloquium, 2018, Edinburgh. Abstracts of the 25th Cochrane Colloquium, 2018. Cochrane Database of Systematic Reviews 2018;(9 Suppl 1). doi:10.1002/14651858.CD201801

[7] Mateussi MV, Lovato FH, Riera R. Evidence-based medicine academic league: a hub of Brazilian Cochrane Centre for translation issues. Evidence-based medicine academic league: a hub of Brazilian Cochrane Centre for translation issues. Abstracts of the 24th Cochrane Colloquium, 23-27 October 2016, Seoul, South Korea. Cochrane Database of Systematic Reviews 2016;(10 Suppl 2). Doi: 10.1002/14651858.CD201602.

[8] Silva AA, Parra MT, Porfirio GJM, Freitas CG, Martimbianco ALC, Torres MFS, Pesavento T, Reiter M, Torloni MR, Riera R, Atallah AN. Translation initiative of the Brazilian Cochrane Centre: experience of the first 8 months. Abstracts of the 22nd Cochrane 
Colloquium, Hyderabad, India. Cochrane Database of Systematic Reviews 2014;(9 Suppl). doi: 10.1002/14651858.CD201402

[9] Logullo P, Teixeira TDBF, Pachito DV, Latorraca CC, Riera R, Torloni MR. Editing podcast scripts for local reality. Abstracts of the Global Evidence Summit, Cape Town, South Africa. Cochrane Database of Systematic Reviews 2017;(9 Suppl 1). Doi: 10.1002/14651858.CD201702.

[10] Students 4 Best Evidence. Website: Available from: https://www.students4bestevidence.net/. Accessed on 14 August 2019.

[11] CONITEC. About Conitec. Available from: http://conitec.gov.br/en/about-conitec. Accessed on 14 August, 2019.

[12] Pachito DV, Riera R, Petramale CA, Gadelha MIP, Hossepian Junior A, Atallah AN. The judicialisation of health in Brazil: a huge challenge that calls for innovative solutions. In:25rd Cochrane Colloquium, 2018, Edinburgh. Abstracts of the 25th Cochrane Colloquium, 2018. Cochrane Database of Systematic Reviews 2018;(9 Suppl 1).

doi:10.1002/14651858.CD201801

[13] Conselho Nacional de Justiça. E-NatJus. Available from: http://www.cnj.jus.br/programas-e-acoes/forum-da-saude/e-natjus. Accessed on 14 August 2019.

[14] Cochrane. Past Colloquia. Available from: https://community.cochrane.org/news/events/colloquium/past-colloquia. Accessed on 14 August 2019.

[15] Health Technology Assessment International. Past Meetings. Available from: https://htai.org/about-htai/history/past-annual-meetings/. Accessed on 14 August, 2019.

[16] REBRATS. Regimento Interno. 2011 Available from: http://rebrats.saude.gov.br/images/Eventos/Regimento_Interno_REBRATS_revisado_V_reun io.pdf. Accessed on 6 August, 2019. 
[17] REBRATS. Membros. Available from: http://rebrats.saude.gov.br/membros. Accessed on 6 August, 2019.

[18] EVIPNet Brasil - Rede para políticas informadas por evidências. Available from: http://brasil.evipnet.org/sobre/. Acessed on 29 August 2019.

[19] Oxford University. The Creation of the Oxford-Brazil EBM Alliance. Fostering excellence in Evidence-Based Medicine research and teaching in Brazil. Available from: https://medium.com/oxford-university/the-creation-of-the-oxford-brazil-ebm-alliance16771315ecca. Accessed on 7 August 2019. 